\title{
Shubhada Bopegamage
}

\section{ENTEROVIRUS INFECTIONS IN NEONATES AND CHILDREN}

\author{
Slovak Medical University (Bratislava)
}

\begin{abstract}
Enteroviruses are prevalent globally. They are transmitted by the fecal oral route and also the respiratory route. Although these viruses cause mild febrile symptoms in immunocompetent humans, their infections result in a wide range of diseases in the neonates and young infants. The pathogenesis of these viruses depends on the host and virus factors. This mini-review makes the readers aware of the seriousness of enterovirus infections in the pediatric population, and to show the necessity of the molecular diagnostics.
\end{abstract}

Key words: enteroviruses, pediatric infections.

Enterovirus (EV) infections are common, and their frequent mode of transmission is by the fecal-oral and respiratory routes (aerosols). Initially, they replicate in the epithelial mucosal cells (M cells) of the pharynx and gut and spread of infection to different organs is via viremia [1]. Typical symptoms associated with enterovirus infections of immunocompetent population are mild fever, febrile conditions, and in specific cases they are also associated with severe clinical manifestations such as meningitis, encephalitis, and myocarditis. These viruses are also associated with chronic infections associated with autoimmunity such as type 1 diabetes (T1D), dilated cardiomyopathy (DCM) [2-4]. The enterovirus infections are self-limiting due to the primary neutralizing antibody responses.

Neonates and young infants are very susceptible to infections due to the absence of innate and adaptive response, though the innate response is the first line of defense as the adaptive immune response is in a naïve stage [5]. Therefore enterovirus infections in newborns and infants may lead to multiple organ involvement such as hand foot and mouth disease, and severe diseases like herpangina, pleurodynia, hepatitis, myocarditis, myopericarditis, pancreatitis, meningitis, encephalitis, paralysis, and neonatal sepsis leading to mortality [6-8]. The EV infections are the most important cause for viral meningitis, accounting for approximately $90 \%$ of all cases for which an etiological agent was identified [6-9].

\section{Transmission in the neonates and infants}

The EV infections may be acquired vertically, in utero, or at the time of delivery or postnatally (antepartum, intrapartum, and postpartum), nosocomial transmission after birth is also known. Some case studies also demonstrated virus isolation from transplacental transmission, amniotic fluid or cord blood
[10-13]. The dominant mode of transmission of serious neonatal infections in neonates have been predicted to be at the time of delivery via contact with maternal blood and fecal material [10-13]. Most common EVs causing infections in the neonates are echoviruses especially type 11 and coxsackie B viruses (CVB) [14]. Although, it may depend on the type of circulating $E V s$ in a particular geographic area. A retrospective data from the south of England [15] shows that enterovirus infections in children with severe clinical manifestations such as sepsis, encephalitis and myocarditis were related to morbidity and mortality and the enteroviruses were identified as CVB, CVA, Echoviruses and EV-71. Modern molecular techniques and possibilities of genetic analysis have helped scientists to discover mutations and recombination in viruses, and to trace the origins of these viruses. Most of all the identification of the genetic changes has helped to classify and identify emerging and re-emerging enteroviruses.

Picornaviruses related to infections in neonates and children either reclassified or considered as emerging or re-emerging viruses

Genus Parechovirus ( $P e V$ ) belongs to the family Picornaviridae. The genus consists of four species, Parechovirus $A$, Parechovirus $B$ (previously known as Ljungan virus), Parechovirus $C$ (Sebokele virus), and Parechovirus $D$ (ferret parechovirus) [15]. Genotypes of the PeV-A contain viruses that cause severe diseases in humans such as meningoencephalitis, seizures, or sepsis-like illness. The human PeVs cause mild respiratory and gastrointestinal symptoms, yet in young children severe clinical manifestations can be observed [9, 16-18]. Human PeV-1 is highly globally prevalent. PeV-1 and PeV-3 cause of viral sepsis-like illness and meningitis in infants and are suggested to be the most pathogenic types. $\mathrm{PeV} 3$ is mostly associated with paralysis, neonatal sepsis-like illness, and sudden death in the neonates [8, 19-22]. Human PeVs have gained importance recently, mostly the modernization of techniques has increased awareness and their clinical importance have played a great part. Different clinical manifestation by various EV types and human PeVs may be related to the differences in their biological characteristics [7].

The species Enterovirus $D$ consists of five (sero) types, EV-D68, EV-D70, EV-D94, EV-D111 (from both humans \& chimpanzees) and EV-D120 (from gorillas). The Human 
rhinovirus (HRV) 87 has been reclassified as the strain of EVD68. EV-D68 cases have been reported more since the year since 2004 [23]. These viruses are associated with mild respiratory symptoms, but several cases appeared as a severe respiratory disease and had to be hospitalized for ventilation [24]. This severe form is accompanied with shortness of breath, wheezing, and respiratory failure. EV-D68 caused more severe disease in patients with history of asthma and reactive airway disease. EV-D68 was maybe associated with acute flaccid myelitis, aseptic meningitis, and encephalitis [25]. EV-D68 has been reported in at least 2 patients with enterovirus-associated encephalitis, suggestive of neurotropism.

Many enteroviruses specifically the $E V-A$ species such as coxsackieviruses A6, A10 and A16 and enterovirus 71 (EV-A71) are associated with the Hand foot and mouth disease (HFMD) [26]. They all belong to the species Enterovirus $A$ of the genus Enterovirus. A typical acute onset appears as a febrile with a maculopapular rash and blisters observed on the hands, feet, and mouth [26]. The infection is self-limiting, but neurological complications may occur $[26,27]$. The other clinical symptoms include nausea, vomiting, sore throat, fatigue, malaise, loss of appetite, irritability, upper respiratory tract infection, gastroenteritis and non-specific rashes [27]. The outbreaks are frequent in form of epidemics in the Asia-Pacific region especially the EV-A-71 which also causes encephalitis but also can give central nervous system (CNS) involvement and cardiopulmonary failure [28]. Though EV-A71 can also be transmitted via oral secretions, vesicular fluid and fomites besides the classical enterovirus transmission routes [29].

In conclusion, enteroviruses are ubiquitous, the several species, genotypes and multitropism causing varying clinical manisfestations makes their diagnosis challenging and yet necessary.

Acknowledgements: We thank the project of the Ministry of Health MZSR 2016/3-RUVZBB-3 and Norwegian financial support mechanism, Mechanism EEA and Slovak Government - Project SK0082 received by S.B. We thank the Centre of excellence of environmental health, ITMS No. 26240120033 , operational Research and development program financed from the European Regional Development Fund.

We also thank the National Reference Centre for Identification of Enteral Viruses, Ministry of Health of the Slovak Republic.

\section{Literature}

1. Wells A.I. Enteroviruses: A Gut-Wrenching Game of Entry, Detection, and Evasion / A.I. Wells, C.B. Coyne // Viruses. - 2019. Vol. 11(5). - P. 460; https://doi.org/10.3390/v11050460

2. Detection of coxsackie $B$ virus specific RNA sequences in myocardial biopsy samples from patients with myocarditis and dilated cardiomyopathy / N.E. Bowles, P.J. Richardson, E.G.J. Olsen, L.C. Archard // Lancet. - 1986. - Vol. I. - P. 1120-1123.

3. Genomic detection of enteroviruses in the myocardium studies on animal hearts with coxsackie B3 myocarditis and endomyocardial biopsies from patients with myocarditis and dilated cardiomyopathy / Koide H., Kitaura Y., Deguchi H., Ukimura A., Kawamura K., Hirai K. // Japaneese Circulation Journal. - 1992. - Vol. 56. - P. 1081-1093. DOI: $10.1253 /$ jcj.56.1081

4. Satoh M. Enteroviral RNA in endomyocardial biopsy tissues of myocarditis and dilated cardiomyopathy / M. Satoh, G. Tamura, I. Segawa // Pathology International. - 1984. - Vol. 44. - P. 345-351.

5. Maródi L. Neonatal innate immunity to infectious agents / L. Maródi // Infection and Immunity. - 2006. - Vol. 74(4). - P. 19992006. doi: 10.1128/IAI.74.4.1999-2006.2006.

6. (2016). Neonatal Enterovirus Infection: Case Series of Clinical Sepsis and Positive Cerebrospinal Fluid Polymerase Chain Reaction Test with Myocarditis and Cerebral White Matter Injury Complications / Jr. F.H. Morriss, J.B. Lindower, H.L. Bartlett [et al.] // American Journal of Perinatology Reports. - 2016. - Vol. 6. - P. e344-e351. DOI http:// dx.doi.org/ 10.1055/s-0036-1593406.

7. Epidemiological survey of neonatal non-polio enterovirus infection in the Netherlands / M.A. Verboon-Maciolek, T.G. Krediet, A. van Loon [et al.] // J. Med. Virol. - 2002. - Vol. 66. - P. 241
8. Human parechoviruses as an important viral cause of sepsis like illness and meningitis in young children / K.C. Wolthers, K.S. Benschop, J. Schinkel [et al.] // Clin. Infect. Dis. - 2008. doi: 10.1086/589752

9. De Crom S.C.M. (). Enterovirus and parechovirus infection in children: a brief overview / S.C.M. De Crom, J.W.A. Rossen, A.M. van Furth // European Journal of Pediatrics. - 2016. - Vol. 175(8). P. 1023-1029.

10. Antenatal and postnatal diagnosis of coxsackie B4: case series / J.C. Hunt, C. Schneider, S. Menticoglou [et al.] // American Journal of Perinatology Reports. - 2012. - Vol. 2. - P. 1 e6.

11. Group B coxsackievirus infections in infants younger than three months of age: a serious childhood illness / M.H. Kaplan, S.W. Klein, J. McPhee, R.G. Harper // Reviews of Infectious diseases. - 1983. Vol. 5(6). - P. 1019-1032.

12. Adverse effects of maternal enterovirus infection on the pregnancy outcome: a prospective and retrospective pilot study / Z. Khediri, C. Vauloup-Fellous, A. Benachi [et al.] // Virology Journal. - 2018. Vol. 15. - P. 70. https://doi.org/10.1186/s12985-018-0978-7

13. Modlin J.F. Perinatal echovirus infection: insights from a literature review of 61 cases of serious infection and 16 outbreaks in nurseries / J.F. Modlin // Reviews of Infectious Diseases. - 1986. Vol. 8(6). - P. 918-926.

14. Neonatal enterovirus infections reported to the national enterovirus surveillance system in United States, 1983e2003. / N. Khetsuriani, A. Lamonte, M.S. Oberste, M. Pallansch // The Pediatric Infectious Diseases Journal. - 2006. - Vol. 25. - P. 889-893. doi: 10.1097/01. inf.0000237798.07462.32 


\section{КОРОТКІ ПОВІДОМЛЕННЯ}

15. Severe Enterovirus Infections in Hospitalized Children in the South of England: Clinical Phenotypes and Causative Genotypes H. de Graaf, E. Pelosi, A. Cooper [et al.] // The Pediatric Infectious Disease Journal. - 2016. - Vol. 35(7). - P. 723-727. doi:10.1097/ INF.0000000000001093.

16. Human parechovirus genotypes $-10,-13$ and -15 in Pakistani children with acute dehydrating gastroenteritis / M.M. Alam, A. Khurshid, S. Shaukat [et al.] // PLoS One. - 2013. Vol. 8. - P. e78377. doi:10.1371/journal.pone.0078377.CrossRefGoogle Scholar

17. Human parechovirus infection in children hospitalized with acute gastroenteritis in Sri Lanka / N.T. Pham, S. Takanashi, D.N. Tran [et al.] // Journal of Clinical Microbiology. - 2011. - Vol. 49. - P. 364366. doi:10.1128/JCM.02151-10.

18. Detection of human parechovirus in stool samples collected from children with acute gastroenteritis in Japan during 2007-2008 / N.T. Pham, W. Chan-It, P. Khamrin [et al.] // J. Med. Virol. - 2011. Vol. 83. - P. 331-336. doi:10.1002/jmv.21740.

19. Abed Y. Human parechovirus types 1, 2 and 3 infections in Canada / Y. Abed, G. Boivin // Emerging Infectious Diseases. - 2006. - Vol. 12. - P. 969-975. DOI: 10.3201/eid1206.051675

20. Human parechovirus infections in Dutch children and the association between serotype and disease severity / K.S. Benschop, J. Schinkel, R.P. Minnaar [et al.] // Clinical Infectious Diseases. - 2006. - Vol. 42. - P. 204-210. https://doi.org/10.1086/498905

21. Boivin G. Human parechovirus 3 and neonatal infections / G. Boivin, Y. Abed, F.D. Boucher // Emerg Infect Dis. - 2005. doi: 10.3201/eid1101.040606

22. Specific association of human parechovirus type 3 with sepsis and fever in young infants, as identified by direct typing of cerebrospinal fluid samples / H. Harvala, I. Robertson, T. Chieochansin [et al.] // Journal of Infectious Diseases. - 2009. - Vol. 199. - P. 1753-1760. doi: $10.1086 / 599094$.

23. Centers for Disease Control and Prevention (CDC). Clusters of acute respiratory illness associated with human enterovirus 68-Asia, Europe, and United States, 2008-2010 // MMWR Morbility Mortality Weekly Report. - 2011. - Vol. 60(38). - P. 1301-1304.

24. Severe enterovirus 68 respiratory illness in children requiring intensive care management / J.E. Schuster, J.O. Miller, R. Selvarangan [et al.] // Journal of Clinical Virology. - 2015. - Vol. 70. - P. 77-82.

25. A cluster of acute flaccid paralysis and cranial nerve dysfunction temporally associated with an outbreak of enterovirus D68 in children in Colorado, USA / K. Messacar, T.L. Schreiner, J.A. Maloney [et al.] // Lancet. - 2015. - Vol. 25. - P. 385(9978), 1662-1671.

26. Immunopathogenesis and Virus-Host Interactions of Enterovirus 71 in Patients with Hand / J.A. Cox, J.A. Hiscox, T. Solomon [et al.] // Foot and Mouth Disease. Front. Microbiol. - 2017. - Vol. 8. - P. 2249

27. Virology, epidemiology, pathogenesis, and control of enterovirus 71 / T. Solomon, P. Lewthwaite, D. Perera [et al.] // Lancet Infectious Diseases. - 2010. - Vol. 10. - P. 778-790.

28. The History of Enterovirus A71 Outbreaks and Molecular Epidemiology in the Asia-Pacific Region / J. Puenpa, N. Wanlapakorn, S. Vongpunsawad, Y. Poovorawan // Journal of Biomed Science. 2019. - Vol. 18, N 26(1). - P. 75. doi: 10.1186/s12929-019-0573-2.

29. Pallansch M.A. Fields Virology. Enteroviruses: polioviruses, coxsackieviruses, echoviruses, and newer enteroviruses / M.A. Pallansch, R. Roos. - Vol. 1. - USA: Lippincott, Williams \& Wilkins, 2001. - P. 840-884.

\section{References}

1. Wells, A. I., \& Coyne, C. B. (2019). Enteroviruses: A gutwrenching game of entry, detection, and evasion. Viruses, 11 (5), 460. Retrieved from: https://doi.org/10.3390/v11050460.

2. Bowles, N. E., Richardson, P. J., Olsen, E. G. J., \& Archard, L. C. (1986). Detection of coxsackie B virus specific RNA sequences in myocardial biopsy samples from patients with myocarditis and dilated cardiomyopathy. Lancet, I, 1120-1123.

3. Koide, H., Kitaura, Y., Deguchi, H., Ukimura, A., Kawamura, K., \& Hirai, K. (1992). Genomic detection of enteroviruses in the myocardium studies on animal hearts with coxsackie B3 myocarditis and endomyocardial biopsies from patients with myocarditis and dilated cardiomyopathy. Japaneese Circulation Journal, 56, 1081-1093. DOI: $10.1253 /$ jcj.56.1081

4. Satoh, M., Tamura, G., Segawa, I. (1994). Enteroviral RNA in endomyocardial biopsy tissues of myocarditis and dilated cardiomyopathy. Pathology International, 44, 345-351.

5. Maródi, L. (2006). Neonatal innate immunity to infectious agents. Infection and Immunity, 74 (4),1999-2006. doi: 10.1128/IAI.74.4.19992006.2006.

6. Morriss, Jr. F. H., Lindower, J. B., Bartlett, H. L., Atkins, D. L., Kim, J. O., Klein, J. M., Ford, B. A. (2016). Neonatal enterovirus infection: Case series of clinical sepsis and positive cerebrospinal fluid polymerase chain reaction test with myocarditis and cerebral white matter injury complications. American Journal of Perinatology Reports, 6:e344-e351. DOI: http://dx.doi.org/ 10.1055/s-0036-1593406.

7. Verboon-Maciolek, M. A., Krediet, T. G., van Loon. A, M., Kaan, J., Galama, J. M, Gerards L. J., \& Fleer. A. (2002). Epidemiological survey of neonatal non-polio enterovirus infection in the Netherlands. J. Med. Virol., 66, 241

8. Wolthers, K. C., Benschop, K. S., Schinkel, J., Molenkamp, R., Bergevoet, R. M., Spijkerman, I. J., Kraakman, H. C., \& Pajkrt, D. (2008). Human parechoviruses as an important viral cause of sepsis like illness and meningitis in young children. Clin. Infect. Dis. DOI: $10.1086 / 589752$

9. De Crom, S. C. M., Rossen, J. W. A., van Furth, A. M. (2016). Enterovirus and parechovirus infection in children: a brief overview. European Journal of Pediatrics, 175 (8), 1023-1029.

10. Hunt, J. C., Schneider, C., Menticoglou, S., Herath, J., \& Del Bigio, M. R. (2012). Antenatal and postnatal diagnosis of coxsackie B4: case series. American Journal of Perinatology Reports, 2, 1 e6.

11. Kaplan, M. H., Klein, S. W., McPhee, J., \& Harper, R. G. (1983). Group $B$ coxsackievirus infections in infants younger than three months of age: a serious childhood illness. Reviews of Infectious Diseases, 5 (6), 1019-1032.

12. Khediri, Z., Vauloup-Fellous, C., Benachi, A., Ayoubi, J. M., Mandelbrot, L., Picone, O. (2018). Adverse effects of maternal enterovirus infection on the pregnancy outcome: a prospective and retrospective pilot study. Virology Journal, 15, 70. Retrieved from: https://doi.org/10.1186/s12985-018-0978-7

13. Modlin, J. F. (1986). Perinatal echovirus infection: insights from a literature review of 61 cases of serious infection and 16 outbreaks in nurseries. Reviews of Infectious Diseases, 8(6), 918-926.

14. Khetsuriani, N., Lamonte, A., Oberste, M. S., Pallansch, M. (2006). Neonatal enterovirus infections reported to the national 
enterovirus surveillance system in United States, 1983e2003. The Pediatric Infectious Diseases Journal, 25, 889-893. DOI: 10.1097/01.inf.0000237798.07462.32

15. de Graaf, H., Pelosi, E., Cooper, A., Pappachan, J., Sykes, K., MacIntosh, I., ... \& Tebruegge, M. (2016). Severe Enterovirus Infections in Hospitalized Children in the South of England: Clinical Phenotypes and Causative Genotypes. The Pediatric Infectious Disease Journal, 35(7):723-7. doi:10.1097/INF.0000000000001093.

16. Alam, M. M., Khurshid, A., Shaukat, S., Rana, M. S., Sharif, S., Angez, N. N., Naeem, M., \& Zahoor Zaidi, S.S. (2013). Human parechovirus genotypes $-10,-13$ and -15 in Pakistani children with acute dehydrating gastroenteritis. PLoS One, 8, e78377. doi:10.1371/ journal.pone.0078377.CrossRefGoogle Scholar

17. Pham, N. T., Takanashi, S., Tran, D. N., Trinh, Q. D., Abeysekera, C., Abeygunawardene, A., ... \& Ushijima, H. (2011). Human parechovirus infection in children hospitalized with acute gastroenteritis in Sri Lanka. Journal of Clinical Microbiology, 49, 364366. DOI:10.1128/JCM.02151-10

18. Pham, N. T., Chan-It, W., Khamrin, P., Nishimura, S., Kikuta, H., Sugita, K., ... \& Ushijima, H. (2011). Detection of human parechovirus in stool samples collected from children with acute gastroenteritis in Japan during 2007-2008. J. Med. Virol., 83, 331-336. DOI:10.1002/jmv.21740.

19. Abed, Y., \& Boivin, G. (2006). Human parechovirus types 1, 2 and 3 infections in Canada. Emerging Infectious Diseases, 12, 969975. DOI: 10.3201/eid1206.051675

20. Benschop, K. S., Schinkel, J., Minnaar, R. P., Pajkrt, D., Spanjerberg, L., Kraakman, H. C., ... \& Wolthers, K.C. (2006). Human parechovirus infections in Dutch children and the association between serotype and disease severity. Clinical Infectious Diseases, 42, 204210. Retrieved from: https://doi.org/10.1086/498905

21. Boivin, G., Abed, Y., \& Boucher, F. D. (2005). Human parechovirus 3 and neonatal infections. Emerg. Infect. Dis. DOI: 10.3201/eid1101.040606.

\section{ЕНТЕРОВІРУСНI ІНФЕКЦIÏ У НОВОНАРОДЖЕНИХ І ДІТЕЙ}

\author{
Шубгада Бопегамаж \\ Словацький медичний університет (Братислава)
}

РЕЗЮМЕ. Ентеровіруси поширені в усьому світі. Вони передаються за допомогою фрекально-орального та аерозольного механізму. Хоча ці віруси спричиняють легкі фребрильні симптоми в імунокомпетентних людей, їх зараження призводить до широкого кола захворювань у новонароджених і дітей. Патогенез цих інорекцій залежить від хазяїна та фракторів вірусу. Це коротке повідомлення дає можливість зрозуміти серйозність ентеровірусних інфрекцій у педіатричній практиці та демонструє необхідність молекулярної діагностики цієї хвороби.

Ключові слова: ентеровіруси, дитячі інфекції.
22. Harvala, H., Robertson, I., Chieochansin, T., McWilliam Leitch, E. C., Templeton, K., Simmonds, P. (2009). Specific association of human parechovirus type 3 with sepsis and fever in young infants, as identified by direct typing of cerebrospinal fluid samples. Journal of Infectious Diseases, 199, 1753-1760. DOI: 10.1086/599094.

23. Centers for Disease Control and Prevention (CDC). (2011). Clusters of acute respiratory illness associated with human enterovirus 68-Asia, Europe, and United States, 2008-2010. MMWR Morbility Mortality Weekly Report, 60 (38), 1301-1304.

24. Schuster, J. E., Miller, J. O., Selvarangan, R., Weddle, G., Thompson, M. T., Hassan, F., ... \& Jackson, M. A. (2015). Severe enterovirus 68 respiratory illness in children requiring intensive care management. Journal of Clinical Virology, 70, 77-82.

25. Messacar, K., Schreiner, T. L., Maloney, J. A., Wallace. A., Ludke, J., Oberste, ... \& Dominguez, S. R. (2015). A cluster of acute flaccid paralysis and cranial nerve dysfunction temporally associated with an outbreak of enterovirus D68 in children in Colorado, USA. Lancet, 25, 385 (9978), 1662-1671.

26. Cox, J. A., Hiscox, J. A., Solomon, T., Ooi, M.-H., \& Ng, L. F. P. (2017). Immunopathogenesis and virus-host interactions of enterovirus 71 in patients with hand, foot and mouth disease. Front. Microbiol., 8, 2249.

27. Solomon, T., Lewthwaite, P., Perera, D., Cardosa, M. J., McMINN, P., \& Ooi, M. H. (2010). Virology, epidemiology, pathogenesis, and control of enterovirus 71. Lancet Infectious Diseases, 10, 778-790.

28. Puenpa, J., Wanlapakorn, N., Vongpunsawad, S., \& Poovorawan, Y. (2019). The history of Enterovirus A71 outbreaks and molecular epidemiology in the Asia-Pacific region. Journal of Biomed Science, 18, 26 (1), 75. DOI: 10.1186/s12929-019-0573-2.

29. Pallansch, M. A., \& Roos, R. (2001). Fields virology (volum 1) USA: Lippincott, Williams \& Wilkins; Enteroviruses: polioviruses, coxsackieviruses, echoviruses, and newer enteroviruses.

\section{Відомості про автора:}

Шубгада Бопегамаж - магістрант, кандидат наук, профресор. Ентеровірусна лабораторія Національного довідкового центру ідентисрікації ентеровірусів. Медичний фракультет Словацького медичного університету, Братислава, Словацька Республіка; e-mail: shubhada. bopegamage@szu.sk;

ORCID account: 0000-0002-8423-5565

\section{Information about the author:}

Shubhada Bopegamage - Master's student, PhD, Professor. Enterovirus Laboratory of National Reference Center for Identification of Enteroviruses. Faculty of Medicine, Slovak Medical University, Bratislava, Slovak Republic; e-mail: shubhada.bopegamage@szu.sk

ORCID account: 0000-0002-8423-5565

Конфрлікт інтересів: немає.

Author has no conflict of interest to declare.

Отримано 18.02.2020 p. 